\title{
A sürgősségi ellátás új területe: az assistance orvostan
}

\author{
Felkai Péter dr. \\ Debreceni Egyetem, Klinikai Központ, Általános Orvostudományi Kar, Belgyógyászati Intézet, \\ Anyagcsere Betegségek Tanszék, Utazásorvostani Tanszéki Csoport, Debrecen
}

\begin{abstract}
A nemzetközi utazások száma a második világháború óta töretlenül növekszik. Az utazók igénye a biztonságra megnőtt, ennek ellenére utazás előtti tanácsadáson csak kevesen jelennek meg. Az utazók 50\%-a valamilyen egészségügyi problémával találkozik útja során, és a biztosító segélynyújtó csoportja - az assistance szolgáltató - elrendezi, figyelemmel kíséri a külföldi betegellátást. A segélynyújtó csoportnál dolgozó orvosnak multidiszciplináris tudásanyaggal kell rendelkeznie a biztosítástechnikai és közegészségügyi, jogi ismeretek mellett. Amennyiben a beteg nem folytathatja útját, haza kell hozni. Az orvosnak azonban a beteg hazakísérése és a külföldi beteg helyszíni ellátása is a feladata. Ezen tevékenységek különböznek a hétköznapok gyakorlatától, és a váratlan, sürgősségi helyzetek kialakulása miatt azt kritikus betegek ellátásában jártas orvosnak kell végeznie. A megbetegedett utazók külföldön való ellátását, illetve a külföldi utazók itthoni orvosi ellátását az assistance orvostan tárgyalja. A protokollok létrehozása, az assistance orvostanban való jártasságot igazoló licencvizsga kialakítása a kritikus betegek ellátását végző szakemberek feladata. Orv. Hetil., 2015, 156(20), 808-812.
\end{abstract}

Kulcsszavak: betegszállítás, utazásorvostan, intenzív terápia, sürgősségi ellátás, oxiológia

\section{Assistance medicine, a novel discipline of emergency medicine}

The number of international travels has been continuously increasing since World War II. Though the travelers' demand for safer ways of travelling appeared, only a handful of them sought pretravel advices. This is the reason why $50 \%$ of the travelers have to face some kind of medical problem during their journey. If they have travel insurance, the company's assistance team organizes, monitors and covers their abroad treatment. A doctor of the assistance team has to find her/his ways in various fields: not only a multidisciplinary medical knowledge is a must for a professional like this, but she/he needs to have a good grasp of the basic idea behind the insurance policy, too. Also, she/he should be familiar with the public health care systems of different countries and some legal knowledge is also needed. If the patients are unable to continue their trip, they must be repatriated. Making a decision about the repatriation's timing and modality requires interdisciplinary medical experience and the approach of a critical care/emergency doctor. Among further tasks for the assistance team's doctor one can find medical escort and on-spot medical visit for foreign patients. Both of these two aforementioned medical activities are highly different from - for example a general practitioner's routine. That is the reason why an assistance doctor has to be familiar with the critical and emergency care. Organizing and monitoring medical treatment for a traveler abroad, providing medical escort, making decisions about repatriation and providing medical help for a foreign patient all fall within the competence of a new medical discipline, the assistance medicine. Creating a body of knowledge, collecting appropriate protocols and establishing postgraduate courses for assistance medicine diplomas are the tasks of the critical care and emergency medicine professionals.

Keywords: patient transport, assistance medicine, intensive care, travel medicine, emergency medicine

Felkai, P. [Assistance medicine, a novel discipline of emergency medicine]. Orv. Hetil., 2015, 156(20), 808-812.

(Beérkezett: 2015. február 19.; elfogadva: 2015. március 26.) 
Az „utazási orvostan” kifejezést egy finn háziorvos használta először az 1977-ben megjelent szakcikkében [1]. $\mathrm{Az}$ orvostudomány múvelői realizálták az utazókat fenyegető veszélyeket, de azt is felismerték, hogy megfelelő prevenciós módszerekkel ezen ártalmak kivédhetőek. Az első nemzetközi konferenciát az utazásorvostan tárgykörében 1988-ban tartották Bázelben. Lassan kialakultak azok - a máig is kutatott - tárgykörök, amelyek az utazási orvostan tudásanyagát képezik. Az utazás-egészség (travel-health) fogalma és prevenciós eszköztára azonban nem elégítette ki a különböző, mai utazási betegségek megelőzését. A szabadidő-sportolók, az expedíciókban résztvevők és a humanitárius szolgálatot teljesítők egyaránt igényt tartanak az utazással összefüggő betegségek gyógyítására, az egészségkárosodások következményeinek enyhítésére is. Az utazók preventív és kuratív ellátásának tudományát nevezzük utazásorvostannak (travel medicine) [2].

\section{Az utazásorvostan kialakulása}

Az igazi, nagy volumenú nemzetközi turizmus kialakulását végeredményben az első világháború utáni időkre tehetjük, ekkor a hadi szállítások alól felszabadult eszközöket az idegenforgalomban hasznosították: ismét megindultak a menetrendszerű hajó- és vasútjáratok, és a menetrendek segítségével tervezhetővé vált a tehetősebb emberek számára a szabadidő utazással való eltöltése. Az utazások gyakoribbá válásával az utaztatási iparág csírái is megjelentek: az utazási csekkek, a szállodaépítkezések és a kevésbé ismert természeti szépségek idegenforgalmi kiaknázásához szükséges infrastruktúra kiépítése.

A második világháború persze visszavetette a bimbózó nemzetközi idegenforgalmat, romba döntötte annak infrastruktúráját is. A háború vége ekkor ismét a hadi célra felhalmozott és feleslegessé vált repülőgépek idegenforgalmi célú felhasználását hozta magával. Mivel ez a közlekedési eszköz gyorsan, nagy távolságokra és sok embert tudott szállítani, megteremtődött a tömegturizmus és az ahhoz kapcsolódó - mára már billiárd dolláros forgalmú - turisztikai iparág. Az utazás új formáinak kialakulása, az a tény, hogy mára már 24 órán belül el lehet érni a földgolyó bármely táját, új, addig nem ismert betegségeket indukált és új kihívások elé állította az orvostudományt is.

Először az utazás indukálta, illetve az utazással kapcsolatos megbetegedések megelőzésének (az utazásegészség, travel-health) tudománya alakult ki, majd új, fiatal diszciplínaként kialakult az utazásorvostan (az angolszász szakirodalomban: travel medicine), amely már nemcsak megelőzni, hanem gyógyítani is képes az utazás provokálta betegségeket. Hazánkban ez a tudományág már „in floribus” alakult ki, lényegében Magyarország Európai Unióhoz való csatlakozásával egyidejúleg [3]. Mivel az utazásorvostan tevékenysége minden országban a helyi sajátossághoz kapcsolódik, hazánkban a tudomány „négylevelü lóheréje”, azaz 4 jól definiált szub- diszciplínája alakult ki, a megfelelő háttérszakmákra támaszkodva, és meghatározott prevenciós és kuratív szinteket alkotva [4] (1. ábra).

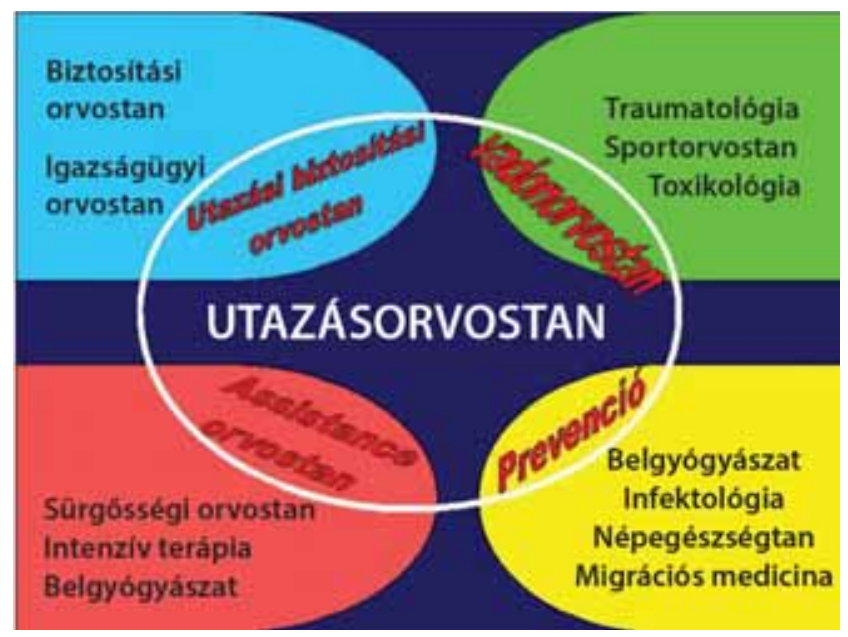

1. ábra Az utazásorvostan 4 szubdiszciplínája: mindegyik több, jól meghatározható tudományágra támaszkodik

\section{Az assistance orvostan fogalma}

A szubdiszciplínák közül a legjelentősebb az intenzíves szakma szempontjából az úgynevezett assistance orvostan, amely a külföldön megbetegedettek ellátásával és - amennyiben szükséges - hazatelepítésével foglalkozik. Mindkét szakfeladat erősen igényli az intenzív terápiás szakemberek kompetenciáját és tudásanyagát.

A magyar orvosok szempontjából a külföldön megbetegedettek két csoportját különböztethetjük meg: a hazánkban megbetegedett külföldi állampolgárokat, illetve a külföldön megbetegedett magyar utazókat. Mindegyik betegcsoportra jellemző, hogy többszörösen kiszolgáltatottak: úgyis, mint betegek, úgyis mint egy idegen nyelvư és egészségügyi szisztémájú országban bajba jutott emberek, akik sok pénzt áldoztak arra, hogy utazhassanak. Mivel a beteg utazóra jellemző az, hogy halasztgatja az orvoshoz fordulást, remélvén, hogy a baj előbbutóbb elmúlik, így sokszor szó szerint is „halálra” disszimulálja magát. A baj előrehaladtával állapota - mutatis mutandis - egyre kritikusabbra fordul, és intenzív ellátásra szorul. A külföldön történt egészségkárosodások túlnyomó többségét a balesetek alkotják, amelyek nagy része mútétre szorul. Így ezeknek a betegeknek az ellátásához is köze van az intenzív-aneszteziológus szakembereknek.

Nyilvánvaló, hogy az az utazó, aki betegsége folytán nem tudja utazását folytatni, haza kell, hogy térjen. Ennek megszervezése és kivitelezése - a repatriáció - szintén a kritikus állapotú beteg ellátásában jártas szakember jelenlétét igényli. Nem véletlen, hogy erre a feladatra a biztosítótársaságok asszisztőr szolgáltatói eddig az in- 
tenzíves, a mentő és a traumatológus szakorvosokat kérték fel.

Az assistance és az asszisztőr kifejezés új fogalompár a magyar orvosi nyelvben, és e helyen ismertetésre szorul. Ismeretes, hogy mára az utazási biztosítások szinte kivétel nélkül assistance jellegúek, azaz a biztosítási esemény bekövetkeztekor a biztosító a kárt szolgáltatás nyújtásával rendezi. Magyarán szólva, amennyiben az utazó külföldön orvosi ellátásra szorul, a biztosító a vele szerződött külföldi partneréhez küldi a beteget (vagy ellátót keres neki), és a betegnek nem kell fizetnie az ellátásért, mert helyette azt a biztosító közvetlenül rendezi az ellátóval. A kárrendezés tehát nem a költségek utólagos rendezésével, hanem a szolgáltató felkeresésével és a szolgáltatás árának közvetlen fedezésével történik. Nyilvánvaló, hogy a biztosító ezt a feladatot minden esetben kiszervezi egy erre a tevékenységre szakosodott „asszisztôr" (a biztosító 24 órán át elérhető segélynyújtó csoportja) cégre.

$\mathrm{Az}$ assistance tevékenységet végző orvosnak tehát (akinek az alkalmazását kívánatos lenne ezen cégeknél is megkövetelni) nemcsak a fenti két fó tevékenységhez kell értenie, hanem emellett még számtalan tudásanyagot kell felhasználnia, így ismernie kell:

- az utasbiztosítás által fedezett ellátás összegeit (hogy ne írjon elö olyan vizsgálatokat, amelyeket nem fizet a biztosító);

- a külföldi egészségügyi ellátás lehetőségeit és szabályozását (hogy a hazai betegeknek ellátási fórumot találjon);

- a légi utaztatás és az utasbiztonsági szabályozásokat (hogy megfelelően készítse fel a beteget az utazásra és a kísérő egészségügyi személyzetet a megfelelő orvosi eszközök összeállítására);

- interdiszciplináris ellátási formákat, beavatkozási lehetőségeket és protokollokat (hogy meg tudja ítélni a külföldi ellátás megfelelőségét és színvonalát).

A külföldi betegek ellátását végző szakember tehát minden esetben az assistance orvostant múveli, ebben kell valamilyen szinten járatosnak lennie. Nyilvánvaló, hogy a fenti tudásanyaggal rendelkező és szakmáját készségszinten múvelő orvos legtöbbször intenzív-aneszteziológus szakember, illetve az kellene, hogy legyen.

\section{A külföldön megbetegedett utazók ellátása}

Sajnálatos módon összehasonlító elemzések az összes utazás alatti egészségkárosodás eloszlásáról még nem születtek, így a halálozási okok oldaláról tudjuk a kérdést megközelíteni. Szakirodalmi adatok alapján az utazás közben beállt halálozások kórokait a 2. ábrán részletezzük [5].

Nyilvánvaló, hogy minden egyes népességcsoport vagy, ha úgy tetszik, a világ különböző régióiban élő utazók eltérő morbiditási és - talán - mortalitási adatokat mutatnak. A volt gyarmattartó országokban a trópusi betegségek akvirálása (és behurcolása az anyaországba)

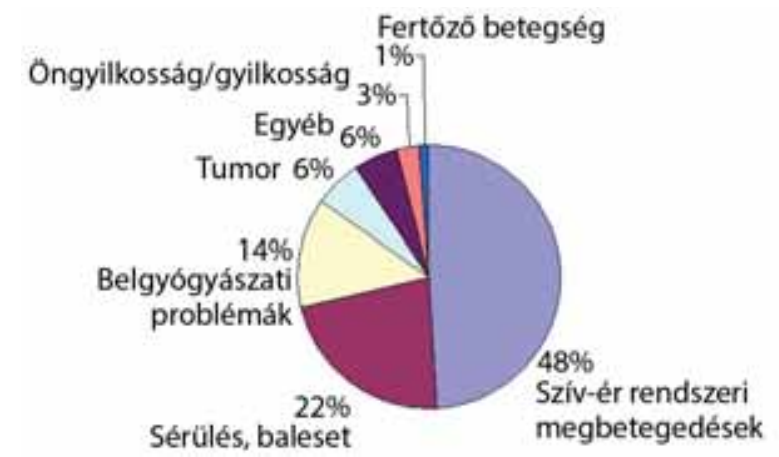

2. ábra $\quad$ Az utazás közben fellépő halálozások okai [5]

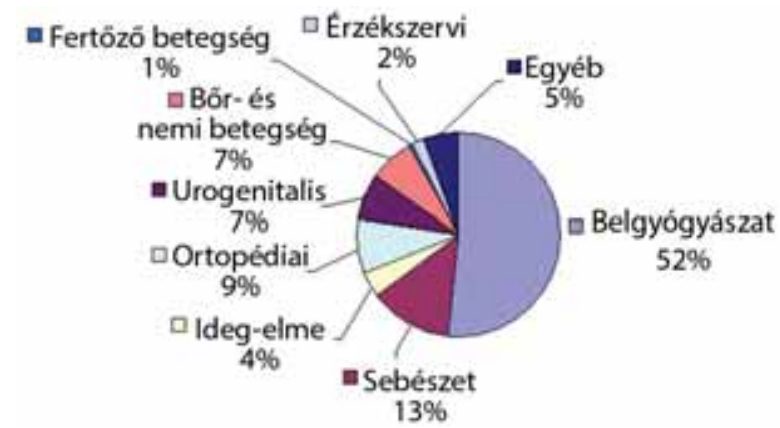

3. ábra $\quad$ A magyar utazók egészségügyi problémáinak megoszlása külföldön

sokkal gyakoribb, mint például a magyar utazók között, akiknek 80\%-a Európán belül utazik, így morbiditási adataik is mások [6] (3. ábra).

Az idegen nyelven alig vagy nem beszélő beteg ellátása teljesen más alapokon történik, mint a beteg saját hazájabeli ellátása. Az anamnézis felvételének nehézségei, az utánkövetés lehetetlensége, az utazó - már említett - disszimulációja és a betegségek kezdeti, amorf tünetei szinte lehetetlenné teszik a pontos diagnózis felállítását. Így a hatásos betegellátás (tudomásul véve azt, hogy minden utazó mindenáron folytatni akarja utazását) igen nehéz, igénybe veszi az oxiológiai és a sürgős betegellátás minden eszközét. Arról már nem is beszélve, hogy a leggyakoribb, utazási diarrhoea okozta exiccosis, a repülés okozta gyakori felső légúti infekciók, barotrauma, a szív- és légzőrendszeri katasztrófák intenzív szemléletú ellátást és sokszor terápiát igényelnek. Különösen igaz ez a tengerparti nyaralás, illetve a szabadidősportok űzése közben előforduló termikus traumák, magassági betegségek, vadállattámadások és ételmérgezések esetében.

Közös alapelv a magyar turista külföldön, illetve a külföldi utazó hazánkban történő betegellátásakor, hogy az utazó külföldön történő megbetegedése - még ha az otthonában „banálisnak” is ítéltetik a kórkép - sohasem banális, inkább azonnali, sürgős beavatkozást igényel. Könnyen belátható, hogy egy alsó végtagi törés (de még egy luxatio is) az utazás végét jelenti: az utazó haza kell, hogy térjen. 


\section{A repatriáció}

A beteg tervezett hazahozatalának folyamatát a szakirodalom repatriációnak nevezi [7]. Ez az orvosi tevékenység élesen különbözik a beteg azonnali, a betegség vagy baleset helyszínéról történő elszállításától, amely abszolút (sokszor vitális) indikáció alapján történik és inkább orvosi evakuációnak nevezzük. Mindkét tevékenység igényli a kritikus beteg ellátásában jártas intenzív szemléletü szakorvos irányítását.

Maga a repatriáció komplex folyamat: kezdődik a betegről szerzett információk értékelésével, ezek alapján a hazaszállítás módjának és idejének a meghatározásával, a beteg szállításra való felkészítésével, a szállítás megszervezésével, a beteg állapotának a helyszínen való ellenőrzésével, a beteg kísérésével és végül a beteg hazájában a megfelelő egészségügyi ellátóegységben való átadásával.

A beteget kísérő orvosnak feladata az idegen ország egészségügyi rendszeréből kihozni a betegét, felügyelni és monitorozni a - sokszor kritikus állapotban lévő - betegét az általában 4-5, de sokszor 12-16 órás repülőút alatt, intézkedni a beteg mozgatásáról a repülőtéren és a kabinban egyaránt. Emellett el kell látni a gondjainkra bízott beteg útközben előforduló rosszulléteit, sőt a repülőn utazó más megbetegedett embereket is, mindezt csekély orvosi felszerelés birtokában, ülésnyi helyen, a repülőgép kabinkörülményei között - a gyors kórházi ellátás reménye nélkül (4. ábra).

Érthető, hogy a fenti feladatokat a kritikus állapotú beteg ellátásában jártas, és - mint worst case scenario ha kell, lélegeztetést, keringéstámogatást kivitelezni tudó szakemberre van szükség, így elsősorban az aneszteziológus-intenzív terápiás szakember jön szóba.

Jelenleg az asszisztőr cégeknek nem kötelező az utazásorvostanban jártas - sőt egyáltalán semmilyen - orvost alkalmazniuk, így a szakmai döntések meghozatala gyenge lábakon áll. Ennek nemcsak a biztosítótársaság

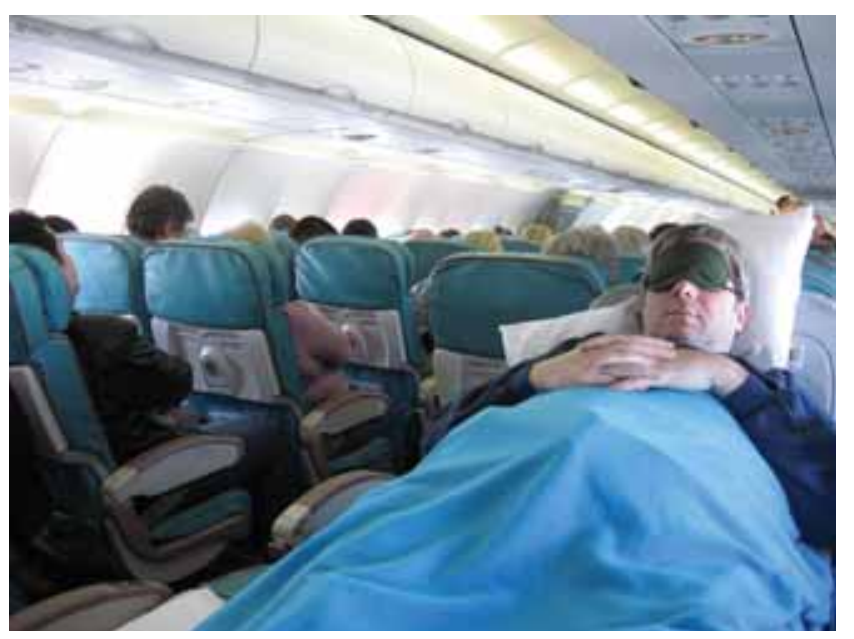

4. ábra $\mid$ Fekvőbeteg-ellátásra rendelkezésre álló hely járatgépen issza meg a levét (mivel nincs módja megítélni a kiszámlázott betegellátási összeg jogosságát), hanem - és legfőképpen - a beteg, akinek egy rossz döntés nagyfokú egészségkárosodást okozhat. Ezért kérik meg az asszisztőr cégek a (külföldi) kezelőorvost, hogy adjon véleményt a hazautazás módjáról (ezt nevezik „fit-to-fly” nyomtatványnak) és így a beteg repatriációjának felelősségét is áthárítják a kezelőorvosra. Sajnos, a kezelőorvos legtöbbször ugyanolyan járatlan az assistance orvostanban, mint megbízója.

\section{Megfelelő ellátóhely biztosítása küilföldön}

Manapság alapvető emberi jog és a szabadidő eltöltésének legnépszerúbb módja az utazás. Nemcsak a mozgássérültek utazását tette lehetővé a legtöbb turistacélpont akadálymentesítése, hanem a repülőtéri szabályozások és a közlekedési eszközök alkalmassá tétele a fogyatékossággal élők számára is elérhetővé tették a külföldi utazást. Egyre több, valamilyen állandó kezelést igénylö, krónikus betegségben szenvedő ember kel útra, és ezen emberek kezelésének külföldön történő biztosítása ügyében a gondozó orvos szintén az assistance orvostanban járatos szakemberhez kell, hogy forduljon. Az ismeretek skáláját jelzi, hogy nemcsak az egyes országokban található dialízisállomások lokalizációját, beutalási rendjét kell ismerni, hanem például a hordozható oxigenizátorok (POC) szervizmúhelyeinek helyét is. Az egyes speciális feladatokra szakosodott egészségi ellátók fellelhetőségét illetően, a külföldi gyógyszerek beszerezhetőségének lehetőségeiről is tájékozottnak kell lenni. Látható, hogy az interdiszciplináris tudásanyag és szemlélet ebben a tevékenységi körben is elengedhetetlen.

\section{A külföldi betegellátás monitorozása}

Sajnálatos módon a külföldi ellátóegységekben a legelső kérdések egyike az, hogy ki viseli a betegellátás költségeit. Fóleg a mediterrán országokban ehhez rendelik az elkért összeget, így, ha a beteg utasbiztosítással rendelkezik, a biztosítót korlátlan finanszírozónak tekintik. (Sok országban a kórházi ellátás összegét le lehet alkudni!) Az ellátóhely és az ellátás megfelelőségének megítélése, a szükségtelen vizsgálatok és beavatkozások elkerülésére való fokozott odafigyelés egyértelmúen egy multidiszciplináris ellátásban jártas szakorvos jelenlétét igényli. Ami a gyakorlatot illeti: a 2004. évi cunami területén tartózkodó turisták ellátása, evakuációja, a járványok megfékezése - többek között - a biztosítótársaságok helyszínre érkező orvosainak tevékenységét is igényelte. A tapasztalatok alapján világossá vált, hogy a biztosítóknál, assistance társaságoknál dolgozó orvosoknak a biztosítástechnikai ismereteken és szervezési jártasságon kívül szükségük van a gyakorló orvosi ismeretekre is [8]. 


\section{$\mathrm{Az}$ assistance orvostan jövője hazánkban}

Látható, hogy az új orvosi szubdiszciplína múvelése interdiszciplináris szemléletű, a kritikus állapotú beteg ellátásában jártas szakembereket igényel. Az assistance orvostan még kialakulóban van, nemcsak hazánkban, hanem külföldön is. Általában ott próbálják megfogalmazni feladatait és tudásanyagát, ahol magát az utazásorvostani diszciplínát is graduális szinten oktatják az egyetemen, jelenleg Európában csak két helyen: az Egyesült Királyságban (Manchester), illetve hazánkban (Debrecen). Az új tudományterület egyébként nehezen találja meg a helyét az orvostudományok rendszerében: az angolszász világban a trópusi medicina, Ausztráliában a katonaorvostan részének tekintik [9]. Jelenleg nincs jogszabályi, illetve szakmapolitikai iránymutatás arra nézve, hogy milyen szakmai végzettséggel és gyakorlati tudásanyaggal kell rendelkeznie annak az orvosnak, aki az alapellátási szinten külföldi beteget kezel, illetve betegkísérési feladatot teljesít a repatriáció alatt. A közleményben leírt követelményrendszereket tekintve célszerü lenne, ha ezt a tevékenységet licencvizsgához kötve lehetne csak végezni, illetve kívánatos lenne, ha az assistance tevékenység többi feladatát is e vizsga letétele után gyakorolnák a biztosító, illetve az asszisztőr cégek orvosai. A szükséges tudásanyagot, az oktatás metodikáját és a vizsgakövetelményeket a sürgősségi ellátás szakmai csúcsát jelentő intenzív terápia, illetve annak szakmai vezetősége célszerü, hogy összeállítsa.

Anyagi támogatás: A közlemény megírása, illetve a kapcsolódó kutatómunka anyagi támogatásban nem részesült.
A cikk végleges változatát a szerző elolvasta és jóváhagyta.

Érdekeltségek: A szerzőnek nincsenek érdekeltségei.

\section{Irodalom}

[1] Hellberg, H.: Travel medicine - a new branch of medicine. [Matakailulääketiede - uusi lääketieten haara.] Duodecim, 1977, 23, 17-18. [Finnish]

[2] Steffen, R., Dupont, H. L.: Travel medicine 2010. In: Dupont, H. L., Steffen, R. (eds.): Textbook of Travel Medicine and Health. 2nd ed. Decker, Hamilton, 2001.

[3] Felkai, P.: Travel medicine and its connection to the insurance policy. [Az utazási orvostan és annak biztosítási vonatkozásai.] Orv. Hetil., 2004, 145(33), 1705-1708. [Hungarian]

[4] Felkai, P.: Travel medicine in Eastern-Europe: the Hungarian way. Travel Med. Infect. Dis., 2008, 6(4), 195-200.

[5] Hargarten, S. W., Baker, T. D., Guptill, K.: Overseas fatalities of United States citizen travelers: an analysis of deaths related to international travel. Ann. Emerg. Med., 1991, 20(6), 622-626.

[6] Felkai, P., Paragh, Gy. (eds.): Testbook of the travel medicine. [Az utazásorvostan tankönyve] Medicina Könyvkiadó, Budapest, 2011. [Hungarian]

[7] Felkai, P., Gorove, L.: The basic considerations on patient repatriation. [A külföldön megbetegedettek hazaszállítása.] Orv. Hetil., 2009, 150(35), 1671-1678. [Hungarian]

[8] Lim, M.: Asian tsunami: Lessons in disaster management from Aceh. 9th Conference of the International Society of Travel Medicine, Lisbon, 2005.

[9] Leggat, P. A.: Travel medicine: profiling an emerging specialty. ADF Health, 2003, 4(2), 72-77.

(Felkai Péter dr., Budapest, Szentendrei út 301., 1039 e-mail: peter.felkai@soshungary.hu)

Az Orvosi Hetilap egyes számai megvásárolhatók a Mediprint Orvosi Könyvesboltban.

Cím: Budapest V., Múzeum krt. 17. - Telefon: 317-4948 